\title{
Typology of Additional Facilities at The Dock of Tambak Lorok Fisherman Settlement in Semarang, Indonesia
}

\author{
Satriya Wahyu Firmandhani \\ Department of Architecture, Faculty of Engineering, Universitas Diponegoro
}

Corresponding e-mail: satriya_firmandhani@yahoo.com

\section{Article info:}

Received: 14-11-2020, Revised: 12-12-2020, Accepted: 13-12-2020

\begin{abstract}
This study aims to explore the typology of additional facilities at Tambak Lorok dock in Semarang, Indonesia. The revitalized dock is in an appropriate condition with permanent materials and additional facilities that naturally added by user. These facilities are intended as spaces to support fishing activities. This study employed a qualitative rationalistic paradigm by collecting primary data in the form of interviews with related actors and physical data in the field. The results of this study revealed two categories of additional space properties, namely static and dynamic. The static additional space has a laying pattern at the edge of the dock bordering the settlement or the sea, whereas the dynamic additional space has a laying pattern at the center of the dock.
\end{abstract}

Keywords: Typology, Additional Facilities, Dock, Tambak Lorok Semarang.

\section{Introduction}

Tambak Lorok Semarang is a fishing settlement that has existed since 1950 and survived from generation to generation to the present. Its inhabitants include fishermen and a variety of other livelihoods, such as labourers, employees and micro, small medium enterprises. The condition of the Tambak Lorok fishermen settlement is considered slum. Regarding the condition of the houses and public facilities, many parts are below road level so tides and floods often occur. Fishermen facilities, including docks and fish auction centre appear inadequate to facilitate fishing activities. The central government of the Republic of Indonesia has attempted to improve the condition by carrying out the construction of Tambak Lorok as Kampung Bahari. This project began in 2018 with the construction of important facilities for fishing settlement, such as markets, docks, and environmental road management. The current condition of Tambak Lorok fishing settlement can be seen in Figure 1.1.

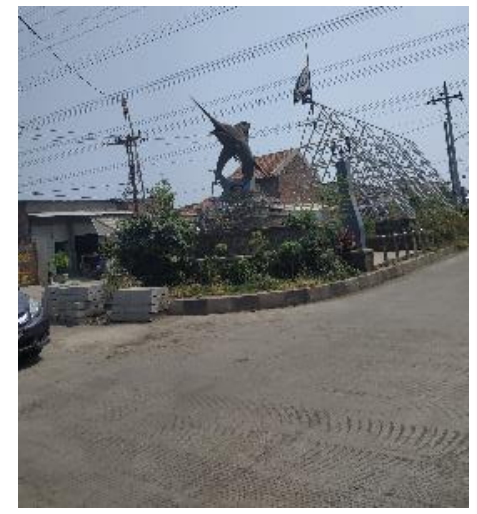

Figure 1.1. The Current Condition of Tambak Lorok in 2020. (Author, 2020) 
Several phenomena occur as backdrops to the government's efforts to revitalize this area. In 2007 a new fish auction place was inaugurated. Initially it was used to auction off the fishing catches of fishermen on Tambak Rejo street with public facilities, such as (lighting and environmental roads). However, the fish auction place was not used by residents after three months of being inaugurated, and now the building has collapsed (Firmandhani \& Alfia Riza, 2018). The existing docks are also made of semi-permanent materials, such as bamboo without any arrangement, thus creating a slum condition and not maintaining the safety of the users. Supporting rooms for fishing activities are also often built around the dock area, such as places for drying fish and repairing boats.

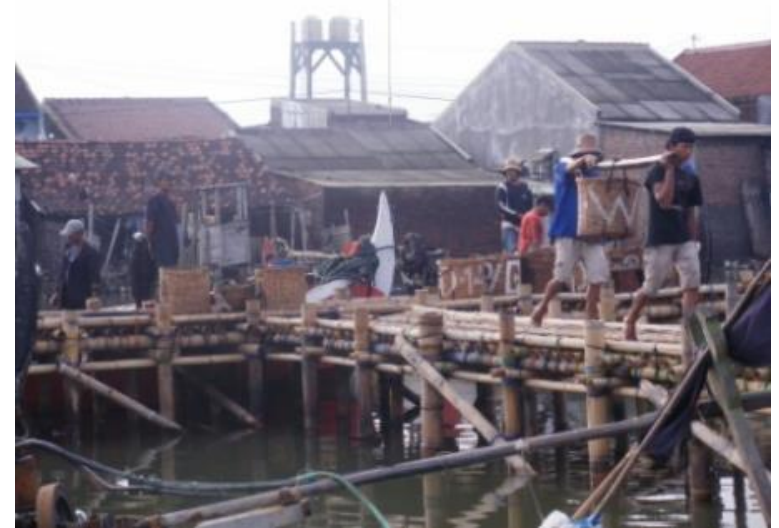

Before Revitalization

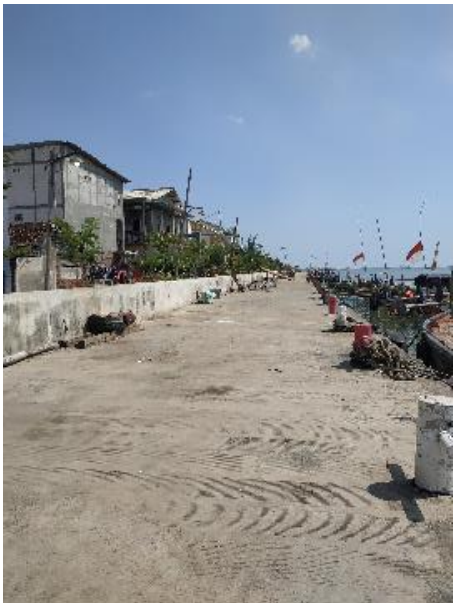

After Revitalization

Figure 1.2. Dock on Tambak Lorok

(Author, 2020)

The current condition of the Tambak Lorok dock has been built with permanent materials, designed to be the border between Tambak Lorok and the bay, which is usually used for fishing boats to dock. An interesting phenomenon occurs, namely the occurrence of additional spaces on the new dock. This space is formed by the existence of physical elements of space and people with activities that contained in it (Pandelaki et al., 2018). The emerging spaces support fishing activities, such as storage, rest rooms, boat repair rooms, boat ramps and fish drying area. From this phenomenon, it is necessary to conduct a study to explore the additional spaces at Tambak Lorok dock. This research explores a new phenomenon that occurs in Tambak Lorok. Several previous studies investigated Tambak Lorok in terms of the typology of interaction space that conducted by inhabitant. There are 3 typologies of interaction space such as primary, secondary and tertiary (Ramandhika, 2019) and the Conceptual Spatial Model for fishermen's settlements that formulated an ideal spatial arrangement in facing the problem and potential (Setioko et al., 2011). Indicators of cultural community in the fishermen settlement have been formulated. One of them is residential environment such as fishermen supporting facilities (Rahmadaniyati et al., 2017). The dock as one of the supporting facility in Tambak Lorok is also quite adaptive, it can be adjusted by using dynamic material - materials which have the ability to change their physical appearance and characteristics (Lelieveld et al., 2007). Based on the previous studies, there are no case that studied the typology of additional space/adapted space, therefore this paper explores it with the case study of Tambak Lorok's dock. It need to be explored to give the understanding of the arrangement and the nature of additional space that naturally adapted by the user. 


\section{Methods}

This research was conducted with a qualitative rationalistic paradigm by examining information from primary sources, namely interviews with the actors involved at the dock, who were in dialogue with existing physical data. Several stages carried out in this research include:

2.1. Grand tour

The grand tour aimed to observe the overall condition of Tambak Lorok as background knowledge and find more detailed issues in the spot investigated in this study, namely the dock area.

2.2. Mini tour

The mini tour became an observation that focused on the investigated spot by collecting physical data. At this stage, initial observations on the phenomena were carried out at the dock, namely the addition of spaces and physical data, such as dock dimensions.

2.3. Interviews

Interviews were conducted with actors who were directly or indirectly involved in adding space on the dock. The directly involved actors were the fishermen who anchored their boats. Meanwhile, the indirectly involved actors included fish auction place officers and residents. The interviews aimed to find out the motivations for adding space, the function of space and the expectations of these actors. The results of the interviews became primary data, then were analysed and dialogued with the physical data obtained.

2.4. Analysis

The analysis stage aimed to find out pattern of additional space on the dock so that in the future it can be used as a basis for structuring a dock in a fisherman's settlement. The analysis was based on the results of interviews and dialogues with physical data.

\section{Result and Discussion}

Before discussing the results of the analysis, it is necessary to review physical data of the Tambak Lorok dock to illustrate the existing conditions. Then, there is an illustration of the physical condition and primary data as a representation, proceeded with the analysis and results.

\subsection{Condition of The Dock}

Tambak Lorok fishing settlement is located in North Semarang District, Semarang City, Indonesia. This settlement is inhabited by a heterogeneous community, not only fishermen, but also employees, traders and labourers. Relevant data to understand in this study include:

\subsubsection{Dock physical data}

The physical data of the dock are in the form of dimensions, functions and distribution of fishermen facilities around the Tambak Lorok dock. The physical data of the dock can be seen in Figure 3.1.

The physical data shows that the dock is the border of the fishing settlement with an offset dimension of 6.5 meters jutting into the bay. The material used is cast concrete with the distribution of fishing facilities in and around it, including:nInside the dock: fish drying room, net maintenance and storage room, fisherman rest room, boat repair room. Around the dock: TPI (Fish Auction Center), SPBN (Fishermen Fuel Station). The location of the TPI is at the center of the dock with inadequate building conditions, only in the form of a small compartment measuring $3 \times 2$ meters used for auction organizers. The auction activities are carried out in a pedestrian corridor with shade in the form of a $3 \times 4$ meter tent. 
The SPBN (Fishermen Fuel Station) location is in the north approaching the end of the land and sea border. However, the SPBN condition is no longer functional.

Tambak Lorok Dock as the research locus was built in 2018 with permanent material using reinforced concrete construction. The dock spaces that are used for the fishing boats dock have additional functions so that adaptations and additional facilities were built independently by users. The additional facilities are in the form of resting place for fishermen, a place to store fishing nets and equipment, a place to dry fish and a place to repair boats. The condition of the dock can be seen in Figure 3.2 .

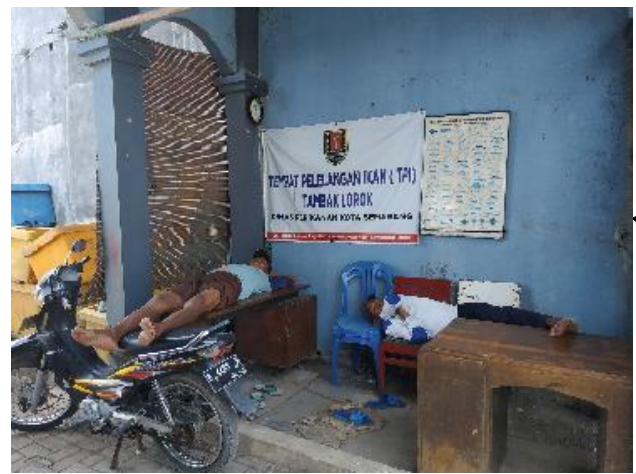

Fish Auction Centre (TPI)

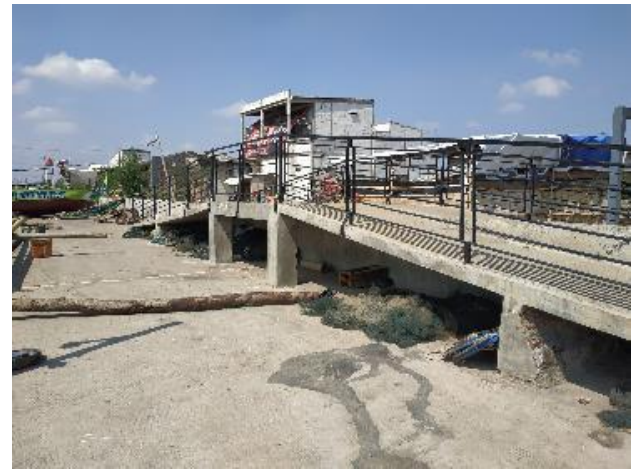

Ramp/Access to settlement
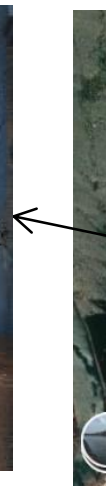
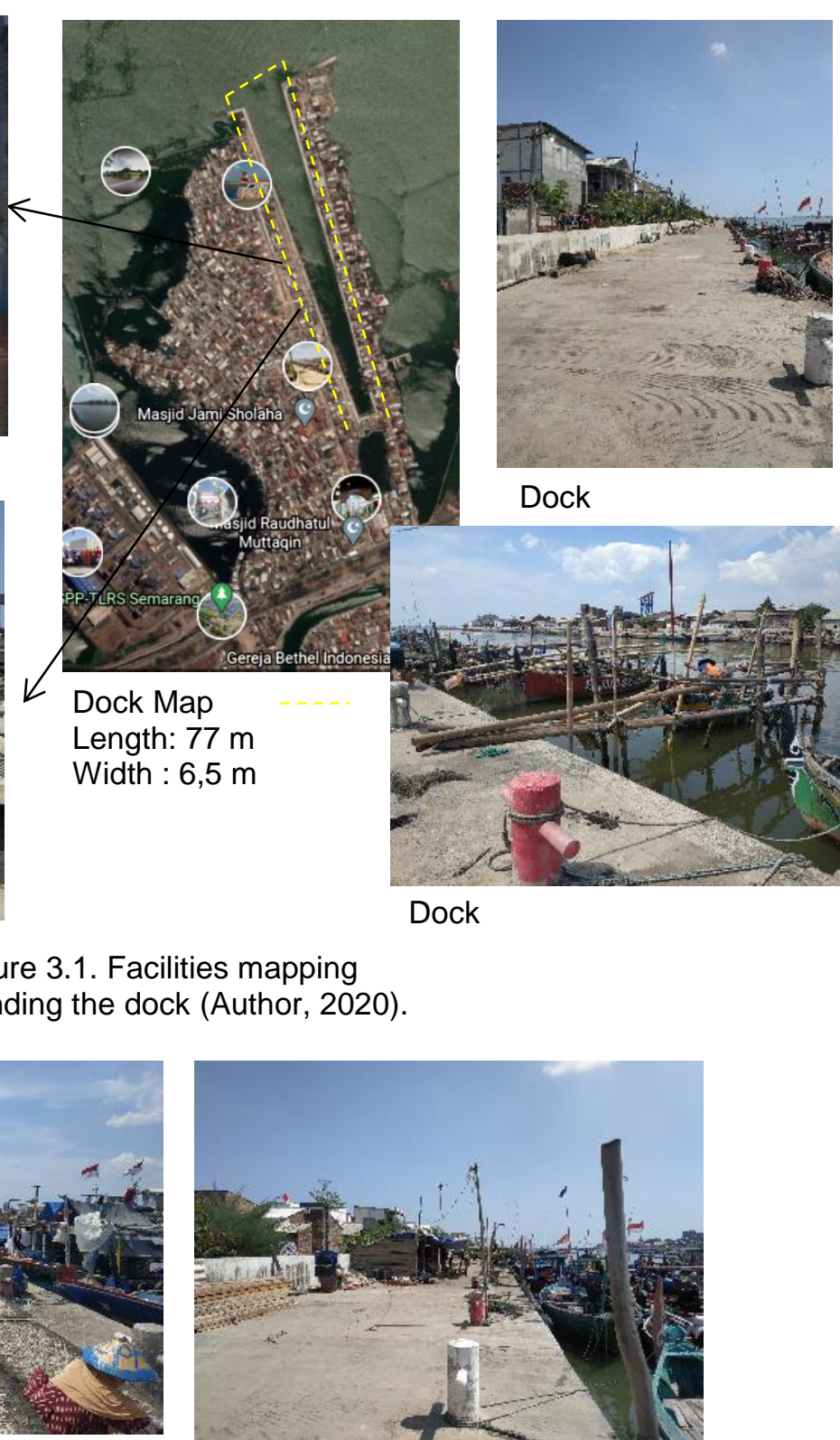

Dock

Figure 3.1. Facilities mapping
surrounding the dock (Author, 2020).
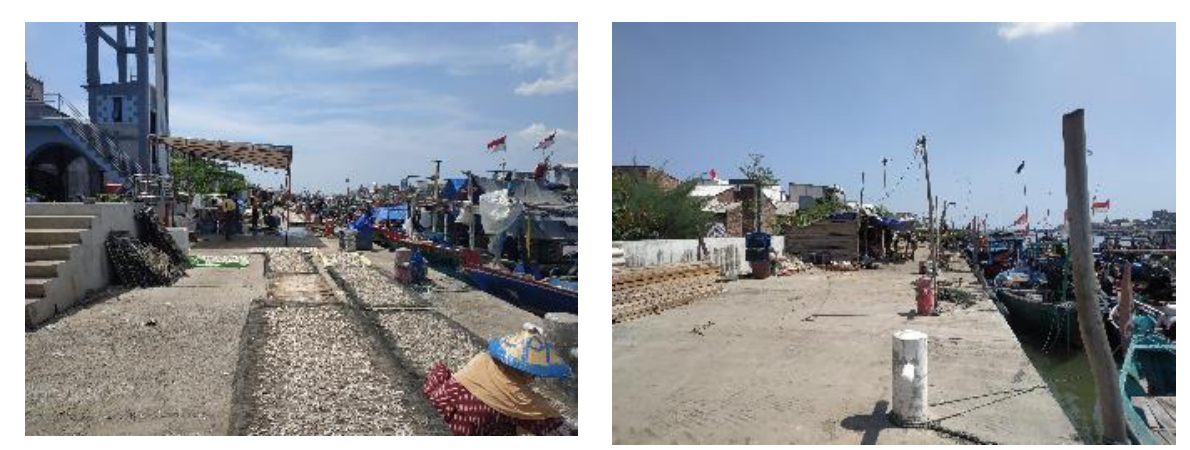

Figure 3.2. Dock's Condition (Author, 2020).

\subsubsection{Interview result}

In the interview process, points of questions were asked and answered openly. These questions include: (1) How do you think the condition of Tambak Lorok dock? (2) Is the dock sufficient for fishing activities? (3) What are your hopes for the future? The three 
questions were asked to the dock users where most of them were fishermen or salted fish makers.

Of the three questions, the answers obtained were almost unanimous, namely grateful for the dock renovation, which is now feasible with permanent material and a width of 6.5 meters. It is quite wide compared to the condition before renovation with wood and bamboo materials with a width of 1-2 meters, making it difficult for fishermen to walk with fish catches. For the utilization of the dock, now it has shortcomings, namely the supporting facilities that are unavailable at the dock, such as boat docks, resting places, tool storage places, fish drying places, so that fishermen take the initiatives to build these facilities independently based on the area where the boat is anchored. This was carried out because fishermen perceived that the dock area was a public area, so everyone could utilize the space. They hoped that the Tambak Lorok dock in the future can be equipped with facilities that support their activities properly as well as other infrastructure, such as a suitable Fish Auction Center.

Interviews were conducted with fishermen who docked their boats at Tambak Lorok dock. Several principles from the interview results were obtained, including:

a. Fishermen thought that the dock area was a public space where everyone could utilize it.

b. Based on the activities carried out in the dock, fishermen needed other facilities, such as storage and maintenance of nets, rest areas on land, a place to repair boats and a circulation route from the dock to the settlement.

c. Many salted fish craftsmen dried the fish in the dock area, thus obstructing the circulation of the dock.

\subsection{Additional Space to Support Fishermen Activities}

Based on the results of interviews and physical data, several points could be attributed to causes and effects:

BACKGROUND

\& PERCEPTION

\begin{tabular}{|c|}
\hline FACILITY \\
REQUIREMENTS \\
\hline DOCK AS A \\
PUBLIC AREA \\
\hline \hline A VAST AREA OF \\
THE DOCK \\
\hline
\end{tabular}

Figure 3.3

Data Scheme (Author, 2020)

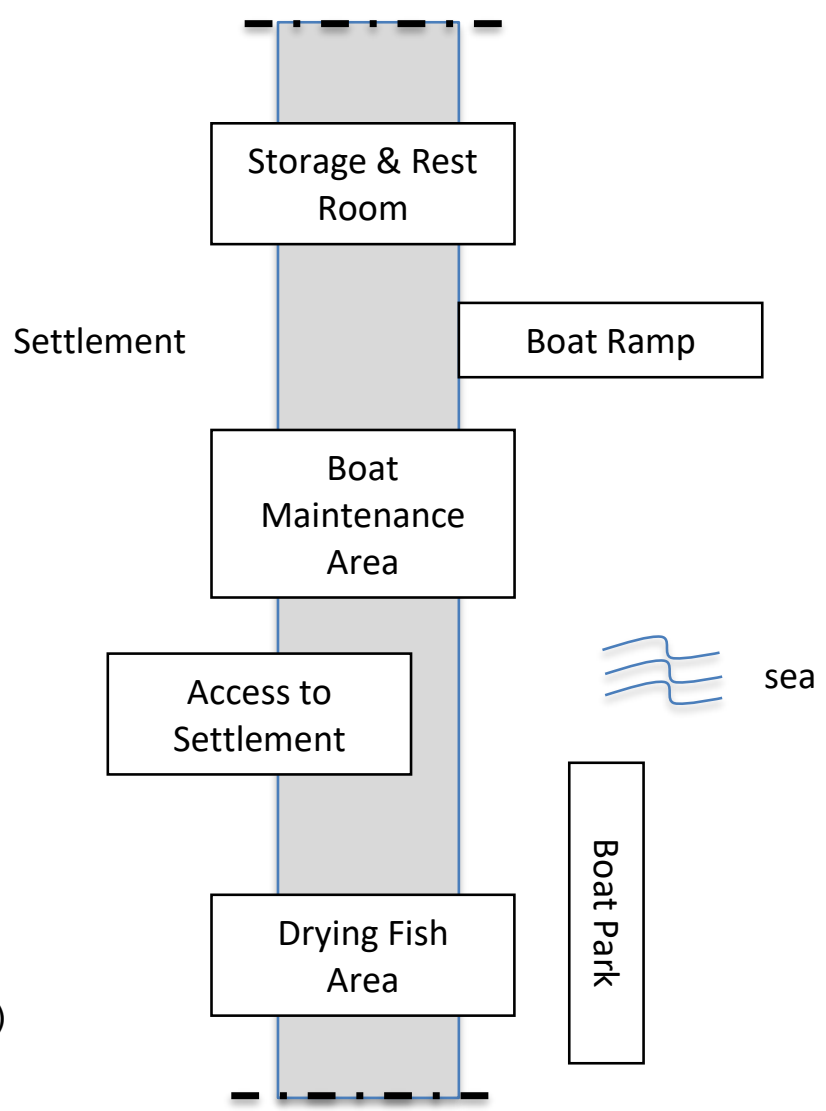


The appearing spaces were an adaptation of dock users to be able to accommodate core activities other than anchoring the boat. The emergence of these spaces was due to the encouragement of perceptions from within the fishermen and the existence of an attractive factor from the environment in the form of dock space, which could accommodate these activities.

3.2.1. Addition of Net and Equipment Storage Area

Storage and maintenance of nets are two of the special activities for fishermen that must be accommodated. Before the dock was built, this activity was carried out on the Tambak Lorok road sections to the terrace of the house. The addition of the storage area for nets and equipment was made with a semi-permanent building made of wood and a tin roof, built on the west side of the dock, bordering the dock and settlement wall. Nets and equipment were also stored under the circulation ramp. Frequently the net storage area was also used for resting fishermen.

The addition of space with more rhythm in the northern part of the dock was also because more fishermen docked in the northern area. In contrast, in the southern area, there were more fish drying.

\subsubsection{Additional Boat Ramps and Boat Repair}

The dock as the fishermen's berth area is the closest inland space to the boat, so that in terms of reach it is the easiest area for boats. The need for boat maintenance must also be accommodated by providing land space for the boat to be repaired. Before the renovation, the boat reparation was carried out at the dock at the end of the alley directly adjacent to the bay. With this dock, fishing boats were also repaired here with various adaptations of facilities by the fishermen, including the circulation space for the boat crane in the form of a wooden ramp to pull the boat up to the dock. Apart from that, the space for the boat reparation is necessary. In the current condition, if there is a boat reparation at the dock, the boat body will cover the dock area so that it will disrupt the circulation of the dock.

The boat reparation is carried out in the area closest to the boat ramp, which is located at 3 spots to the south (1 spot) and north (2 spots).

\subsubsection{Additional Fish Drying Areas}

The fish drying area is an area used for salted fish craftsmen to dry fish. This drying activity is often found in empty spaces in Tambak Lorok, including at the dock. It is usually carried out in the southern area adjacent to the fish auction center. In addition, several points in the dock corridor adjacent to the craftsmen's homes become the areas for the drying activity, including on the west side by the wall or in the middle of the dock.

\subsubsection{Addition of the dock circulation area to the settlement}

Tambak Lorok Dock is 6.5 meters protruding into the bay bordered by a brick wall as high as 1.2 meters along the dock corridor. A permanent access from the settlement to the dock is in the form of a ramp. The width of the ramp is 1.8 meters with hollow iron railings. The location of the ramp is considered inadequate for circulation due to only three points of the ramp, namely in the south adjacent to the fish auction center, in the middle and at the northern end. Three ramps along the dock corridor with a length of $400 \mathrm{~m}$ were considered insufficient so that users have renovated the area with the addition of semi-permanent ladder facilities made of wood for circulation from the dock to the settlement. 


\subsection{Additional Space Pattern}

The analysis process obviously shows various additional spaces at the Tambak Lorok dock. The additional space can be categorized as a space to support fishermen's activities, forming a pattern following the design of the dock that extends across the bay. Based on the distribution of the adaptation of the facilities, it shows the pattern of placing the additional facilities by overlaying all the existing distributions. Regarding the pattern of additional facilities, it appears that circulation access facilities and additional space (non-portable) are placed on the west side of the dock adjacent to the wall, whereas portable and temporary facilities that require a large space are placed in the middle of the dock, such as a fish drying area and boat repair. Additional facilities for the boat ramp are located to the east to access the dock from the sea. The distribution has a character where the drying area for fish is in the south approaching the fish auction centre, while the boat repair area is in the north followed by a boat ramp. The resting space for fishermen and tool storage are spread across almost all areas of the dock, but they are quite concentrated in the northern part of the dock because more boats are docked in the northern area. The additional space in Tambak Lorok Dock reflects the adaptive nature of the dock where additional space is based on physical ambience from post occupancy evaluation (Demers et al., 2013).

From this funding, it can be seen that there are 2 characteristics of additional space on the Tambak Lorok dock namely static and dynamic. The both characters support the fishermen activity on Tambak Lorok and divided based on the location and the nature of the space whether movable or not. The additional space such as ladder/access to settlement, boat ramp, fishermen rest room and storage are categorized as a static additional space. Boat repair area and fish drying area are categorized as dynamic additional space.

Mapping of additional facilities can be seen in Figure 3.4 and the location pattern of additional space can be seen in Figure 3.5. 


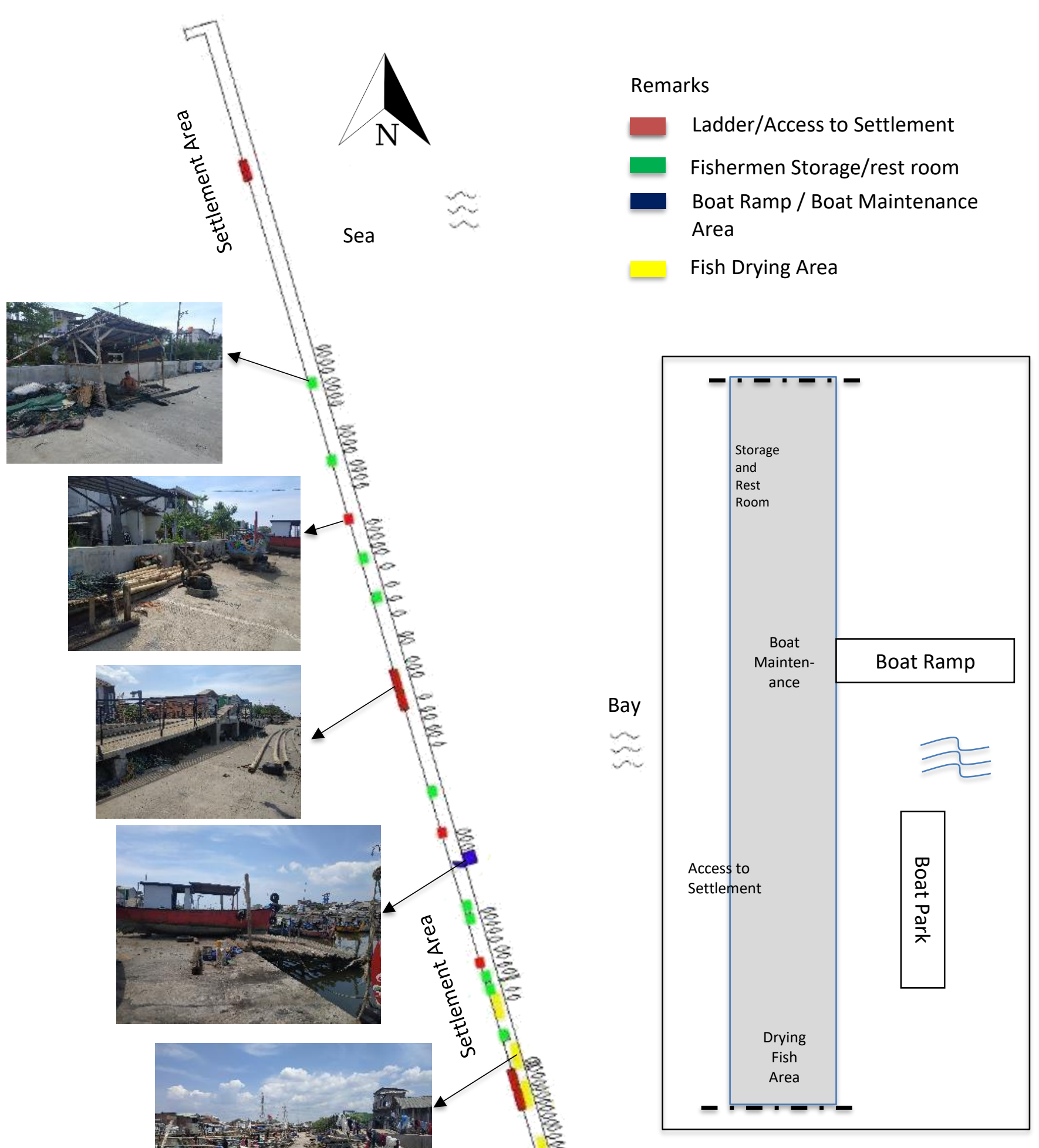

Figure 3.5

Location Pattern of Additional Facilities (Author, 2020) Not to Scale

Figure 3.4

Illustration Mapping of Additional Facilities

(Author, 2020)

Not to Scale 


\section{Conclusion}

The additional supporting spaces at Tambak Lorok dock have two characteristic categories, namely static and dynamic supporting spaces. The additions of static supporting spaces with semi-permanent materials are in the forms of storage space, fishermen rest room, dock access to settlements and boat ramps. Meanwhile, the dynamic supporting spaces are in the forms of a fish drying area and a boat repair area. The pattern of laying out the static supporting spaces is at the border between the dock and the settlement as well as the dock to the sea, while the pattern of laying the dynamic supporting space is in the center area of the dock.

\section{Acknowledgments}

The author would like to thank all people who have supported this research, especially the residents of Tambak Lorok Semarang, Indonesia who have provided primary information in this research.

\section{References}

Demers, C., Potvin, A., \& Giguère-Duval, H. (2013). Inhabiting Adaptive Architecture: Environmental Delight in Adaptable Spaces. Proceeding of International Conference on Adaptation and Movement in Architecture (ICAMA2013), 58-70.

Firmandhani, S. W., \& Alfia Riza, M. A. (2018). Causal Factors in Resilience of Old Tambak Lorok Fishing Port in Semarang. IOP Conference Series: Earth and Environmental Science, 213(1). https://doi.org/10.1088/1755-1315/213/1/012006

Lelieveld, C. M. J. ., Voorbij, A. I. ., \& Poelman, W. . (2007). Adaptable Architecture. Proceedings of Building Stock Activation, 245-252.

Pandelaki, E. E., Suprapti, A., \& Firmandhani, S. W. (2018). Typology of social space in Kauman Kampong Semarang. IOP Conference Series: Earth and Environmental Science, 99(1). https://doi.org/10.1088/1755-1315/99/1/012011

Rahmadaniyati, D., Faqih, M., \& Septanti, D. (2017). Maritime Culture Indicators for theDevelopment of Fishermen's Settlement. International Journal of Innovative Science and Research Technology, 2(6), 4430447.

Ramandhika, M. (2019). TIPOLOGI RUANG INTERAKSI DI PERMUKIMAN NELAYAN TAMBAK LOROK KOTA SEMARANG. Jurnal Proyek Teknik Sipil, 2(2), 1-6.

Setioko, B., Murtini, T. W., \& Pandelaki, E. E. (2011). CONCEPTUAL SPATIAL MODEL OF COASTAL SETTLEMENT IN URBANIZING AREA. International Journal on Architectural Science, 8(3), 60-66. 